Marthe Handå Myhre

Department of Literature, Area Studies and European Languages, University of Oslo

ILOS, P.O. Box 1003 Blindern, Norway

Email: m.h.myhre@ilos.uio.no

$+4795796608$

Marthe Handå Myhre is a PhD Candidate in Russian studies. Her PhD project focuses on the politics and perceptions of citizenship in post-Soviet Russia. Her scholarly interests are related to migration, citizenship studies, governance structures and national identities.

Acknowledgements:

I would like to thank all who have read and contributed with comments and suggestions at various stages of this manuscript's progress. I am especially indebted to Pål Kolst $\varnothing$, Sverre Rustad, Egle KesylyteAlliks, Caress Schenk and Christine Lukash.

The field work for this study was made possible thanks to a travel grant from the Faculty of Humanities, University of Oslo

Word count including abstract and references: 9881 


\title{
Forced migrant "compatriots" from Ukraine Accessing legal residency and citizenship in the Russian Federation
}

\begin{abstract}
This paper enquires into the Russian migration and citizenship regime as encountered by forced migrants from Ukraine who fled to Russia in the period 2014 - 2016. Based on legal and other official documents, media articles and interviews, it gives an account of these migrants' reception in Russia in theory and practice. Russia made great efforts to accommodate them, and in Russian media they were often spoken of as an easily integrated labor resource and as potential citizens. In 2015 - 2016, around 165,000 Ukrainians acquired Russian citizenship. While ethnocultural similarity does privilege Ukrainian migrants in Russia, full asylum has been granted sparingly, and citizenship is not unconditionally granted. As this paper shows, Russian authorities have rather tried to control and distribute these forced migrants for the benefit of the state, according to principles of selectivity and economic interests - giving privileged access to permanent residency and citizenship to working-age people willing to settle in regions where population growth and more workers are deemed necessary. However, permanent residency and citizenship are also available to those able to circumvent or pay their way through the obstacles encountered - taking advantage of the flexibility inherent in a system that is not totally consistent.
\end{abstract}

Keywords: integration, citizenship acquisition, migration, forced migrants, refugees, Russia, Ukraine

When the conflict and war in southeastern Ukraine escalated in 2014, many Ukrainians fled to neighboring Russia. According to UNHCR, Russia received 274,700 asylum applications in 2014, making it the world's largest recipient of new individual applications for asylum that year (UNHCR Country Statistics). In summer 2015, the Russian Federal Migration Service 
$(\text { FMS })^{1}$ estimated that 1 million of the 2.6 million Ukrainian citizens in the country were immigrants (vykhodtsy) from southeast Ukraine (Vashchenko 2015). The authorities responded rapidly, putting in place arrangements for these Ukrainians' shelter and prolonged stay in Russia. The opinion that the Ukrainians constituted a labor resource and a "citizen" potential was repeatedly expressed in the Russian media from the beginning of the war in Donbas. In an interview with $R G$ on September 24, 2014, Konstantin Romodanovskii, then head of the FMS, stated: "this is not only about the Ukrainians' wish to temporarily leave the conflict zone, but also [their wish] to stay forever in Russia. This is logical. The Ukrainian migrants do not need complicated adaptation and integration since we have common cultural and historical values and similar (simmetrichnye) understandings (podkhody) of education and professional qualifications" (Domcheva and Panina 2014). In a RIA Novosti article on July 26 that year, "experts on migration" were quoted as saying: "If all these people will stay with us, it will be good. We have always welcomed the migration of Russian-speaking Slavic migrants as an alternative to migrants from Central Asia” (“Ukrainskie bezhentsy...”).

Despite the large numbers, this migration from Ukraine has attracted limited attention outside Russia, in the mass media or academic journals. In Russia's rapidly changing and sometimes inconsistent migration regime, the coordinated efforts across regions and all levels of administration and the financial allocations made in relation to this influx were exceptional (Schenk 2016). Very few of the Ukrainian citizens fleeing to Russia got asylum (200-300), but many were granted temporary asylum (TA) (311,134 in 2015), and in 2015 as many as

\footnotetext{
${ }^{1}$ By the end of 2016 the FMS was liquidated and its responsibilities transferred to the Ministry of the Interior (MVD).
} 
65,000 and in 2016 more than 100,000 acquired Russian citizenship (Petrov, 2016). ${ }^{2}$ Others, however, remained ordinary labor migrants, two years after their arrival.

This paper examines the legal and regulatory practices used by the Russian authorities to integrate people fleeing Ukraine after the outbreak of conflict and war in the spring of 2014, and these forced migrants' encounters with the Russian citizenship regime. The UNHCR recommends referring to groups of people travelling in mixed movements as "refugees and migrants". Here I find the more open-ended term "forced migrants" suitable, because it stresses the fact that people felt forced to leave - whether from actions of war, economic or other reasons, regardless of what legal status they obtained in the host state. As reflected in the interview material on which the article is based, in Russia several terms were used. Most often "refugees" (bezhentsy) and "migrants" (pereseletnsy).

Inquiring into how a state actually receives such large groups of migrants gives insights into how its refugee, migration and citizenship regimes function. It also allows assessment of prevailing perceptions of membership - the community of value ${ }^{3}$ - in that state and how this is reflected in official policies of inclusion and exclusion. What does the reception of the forced migrants from Ukraine reveal about Russia's refugee, migration and citizenship regime, its priorities and capability? What legal statuses have these migrants obtained in Russia? What was decisive for obtaining the various statuses? How accessible has Russian

${ }^{2}$ Citizenship acquisition in Crimea after the Russian annexation is beyond the scope of this paper. As the majority of the population of Crimea got Russian citizenship already in 2014, figures on Ukrainian citizens acquiring Russian citizenship in 2015 and 2016 are not affected by the annexation.

\footnotetext{
${ }^{3}$ This is the term used by Bridget Anderson (2012), elaborated on below.
} 
citizenship been, and what paths to citizenship have been available? In answering these questions, the paper enters into debates on state policies of preferential integration and naturalization. It discusses how the forced migrants from Ukraine, due to their presumed shared ethno-cultural identity with Russians, were privileged compared to other groups of migrants, and other factors crucial for their integration.

The empirical material used consists of relevant law texts and official documents that regulated the Ukrainian citizens' stay in Russia in the period from spring 2014 to spring 2016, as well as media articles from the same period. The study also goes behind the welcoming rhetoric of the Russian press and officials and includes Ukrainian forced migrants' own perceptions of their possibilities for achieving temporary residency or full integration in Russia. Semi-structured interviews were conducted with 37 Ukrainian forced migrants, as well as some volunteers and NGO representatives working closely with them, in six Russian regions. Respondents were recruited through the social media platform "Vkontakte," where the forced migrants themselves and their helpers had gathered in regionspecific groups with names like "Help to the refugees from Ukraine in Tula." All interviews were conducted between February and October 2016 in five regions of Central Russia (Tula, Lipetsk, Voronezh, Moscow, Moscow Region) and in Novosibirsk. Moscow and Moscow Region are traditional migrant hubs where the authorities have implemented measures to limit rather than encourage migration (Light 2017). During the period studied, the other four regions showed readiness to accept significant numbers of immigrants for permanent

\footnotetext{
${ }^{4}$ Names of the VK groups: "Pomosh' bezhentsam s Ukrainy v Tule," "Pomosh' bezhentam iz Ukrainy v Lipetske," "Pomosh' bezhentsam iz Ukrainy v Voronezhe," "Donbas v Moskve. Pereselentsy, bezhentsy," "Pomoshch bezhentsam s Ukrainy. Novosibirsk". Personal requests were sent to group members with open profiles. Four informants were recruited at two state run centers for temporary residence in Voronezh and Lipetsk.
} 
residency. ${ }^{5}$ It thus seemed likely that in the selected regions I could get in contact with people at different stages and with different experiences of the migratory process, holding various legal statuses in Russia.

\section{Access to the "Community of Value" for Public Relatives}

Legally speaking, migrants and refugees are non-citizens, on arrival regarded as short-term residents who only with time may become permanent residents or even citizens (Anderson 2012). The possibility of becoming a citizen, a formal member of the state, is not equally available to all migrants; for some, the process of acquiring citizenship, if at all possible, may take years, whereas others get preferential access and gain citizenship quickly.

The citizenship laws of many countries privilege people considered to have special ties with that country. As recently as in 2011 Hungary introduced amendments granting preferential access to former Hungarian citizens and descendants who speak Hungarian but live outside the country as a result of the disintegration of the Austro-Hungarian Empire. Costica Dumbrava speaks of those who are granted privileged access to citizenship based on such special links as "public relatives," in contrast to "private relatives"- parents or children. There are two types of "public relatives": "political relatives" are foreigners who get privileged access because they are citizens of certain states, former citizens or descendants of former citizens; "ethno-cultural relatives" have national, ethnic or cultural ties to the country, making them eligible for simplified naturalization procedures - these are people who share

\footnotetext{
${ }^{5}$ For MVD statistics on the migration situation in 2016 see https://xn--b1aew.xn-p1ai/upload/site1/document_news/009/359/228/stat_2016.pdf
} 
specific cultural features with citizens of the country and members of a particular ethnocultural community (Dumbrava 2014, 47).

Bridget Anderson argues that "modern states portray themselves not as arbitrary collections of people hung together by a common legal status, but as a 'community of value', composed of people who share common ideals and (exemplary) patterns of behavior expressed through ethnicity, religion, culture, or language" (2013). Part of these patterns of exemplary behavior are also people's ability to acquire skills needed in society, to work, and generally contribute to the wellbeing of society and provide for themselves, and not become a burden. In a comparative study of migration policies in 45 countries, Hein de Haas et al. found that the tendency in migration policies since 1945 has not been more restrictions, but rather a focus on migrant selection according to criteria such as skills, education, wealth or other class markers (de Haas et al. 2016, 30). States have become more concerned with who is allowed to immigrate: “...migration has been increasingly 'commodified' as part of a utilitarian discourse focusing on the purported economic 'value' of migrants and exemplifies the continued relevance of class in migration policies" (de Haas et al. 2016, 27). Policies targeting specific nationalities have declined. Moreover, when applied, the nationality criteria have "moved from being the historical tool to deny entry of particular groups altogether (which would now be considered discriminatory) to a tool to grant privileged access to particular nationalities" (de Haas et al. 2016, 28).

Culturally the Ukrainian forced migrants are close to the Russian "community of value," and the older generations share a common Soviet past: they fit into a "compatriot" notion used by Russian authorities that includes not only Russian citizens, but potentially all former Soviet citizens and descendants of people who at some point lived on the territory of the Russian 
Federation, whether in Tsarist Russia, the Soviet Union or later (Shevel 2013a; Pilkington 1998). Some of them regard themselves as ethnic Russians and have Russian as their mother tongue or at least speak fluent Russian. Moreover, many Ukrainian migrants are highly educated and/or have professional skills that are needed in Russia. Russian authorities have deemed it necessary to "activate efforts to attract working-age immigrants for permanent residency in Russia" and "to attract migrants in compliance with demographical needs and the socio-economic developments...”. Fully integrating Russian-speaking Ukrainians is thus in line with the stated official aim of increasing the population of Russia (also through substitutional migration) to 145 million by 2025 (Kontseptsiia 2007).

Thus, although the ethno-cultural link also comes into play when Russia grants Ukrainian forced migrants simplified access to citizenship, I hold that this is combined with a certain selectivity based on the migrants' economic "value" and their willingness to serve the country's interest - but also on the migrants' own ability to abide by or circumvent the prevailing and to some extent inconsistent regulations.

\section{Various Legal Paths into Russia for Ukrainian "Compatriots"}

In 2014 an information leaflet for "citizens from Ukraine, forced to leave the territory of Ukraine" was issued by the FMS and distributed through the web-pages of local authorities around the country. The leaflet outlined several ways for migrants to prolong their stay in Russia 
that were available to the Ukrainians, including legal statuses of a clearly temporary and of a permanent character (Pamiatka n.d.). ${ }^{6}$

The first possibility was simply to bring the migration card (issued upon arrival) to a local FMS office for an extension of the 90-day period that Ukrainian citizens may normally stay in Russia in the course of 180 days. $^{7}$ Local departments of the FMS had been "ordered to prolong the stay of Ukrainian citizens without hindrance for the duration of the crisis in Ukraine (na period vnutriukrainskogo krizisa)" (Pamiatka n.d.).. Initially, the stays of all Ukrainian citizens were extended, regardless of whether they had fled from war in Donbas, from unemployment in Western Ukraine, or had come for other reasons. In August 2015, however, the FMS announced that extension of migration cards would apply only to people from the war-stricken selfproclaimed republics of Lugansk and Donetsk; other Ukrainian citizens in Russia would have to clarify their migration status (“Ukraintsy s 1 Augusta...”).

Returning to the leaflet, another option for Ukrainian citizens, as well as other migrants, to legalize their stay was applying for a temporary residence permit (TRP), a legal status in Russia regulated by regional quotas and granted for a three-year period (after which one may apply for

\footnotetext{
${ }^{6}$ This document was referred to already in June/July 2014. Some regions included this leaflet into a larger information brochure. The information is also posted on the web page of the MVD migration department under the headline: "Citizens of Ukraine and persons without citizenship, permanently living in Ukraine, staying in Russia according to emergency mass procedure," available at https://xn--b1ab2a0a.xn--b1aew.xn-p1ai/upload/site1/document_file/3o5gIOPDD8.pdf

${ }^{7}$ Since February 182017 people from Donetsk and Lugansk may use documents issued by the self-proclaimed republics for travels in Russia. See http://en.kremlin.ru/events/president/news/53895.
} 
permanent residency, PR). Yet another option was to apply to the FMS for asylum or temporary asylum, or to apply for Russian citizenship as a "Russian-speaker." This category had been recently implemented in the law on citizenship, adding to other categories already eligible for acquiring citizenship by simplified procedures (Federal Law 62-FZ of May 31, 2002, Article 14, section 2.1, version No 307-FZ of June 23, 2014, and No 307-FZ of October 14, 2014).

Ways of economic and educational migration were also kept open: Ukrainian citizens could get their stays extended if the FMS received an application from the employer confirming that s/he was hiring the Ukrainian citizen as a highly qualified specialist or if the (state-approved) educational institution in Russia where the Ukrainian citizen was studying applied for an extension of his/her stay. ${ }^{8}$ Ukrainian citizens could also remain in Russia by obtaining a labor permit or a patent (valid for one year at a time) - in reality an advance tax payment that allows migrants from several post-Soviet states to work within the region where the patent is obtained. Thus in the very same document, asylum and ways of economic migration were listed, with no clear distinctions as to who was eligible for what. Further information had to be obtained at FMS offices.

\section{Activating Temporary Asylum}

Although Russian authorities were willing to prolong the migration cards of the Ukrainian citizens, at least those from Lugansk and Donetsk, without further ado, this did not give them the

\footnotetext{
${ }^{8}$ Special arrangements were made for Ukrainian citizens who wanted to start or continue their studies in Russia. The Ministry of Education and Science assured Ukrainian citizens that they would be admitted to Russian universities on equal terms with Russian citizens, and capacity was increased at several universities, primarily in the border regions.
} 
right to work in Russia. To enter the labor market legally, they had to obtain a legal status that permitted work. In July 2014, the Russian government issued regulations “on the Granting of Temporary Asylum to Citizens of Ukraine on the Territory of the Russian Federation"

(Government Regulation 690). A set of "temporary rights" included in the regulation promised to process the application for TA within three working days. If TA was granted, a certificate was to be issued within one day, if the applicant and family could document that they had undergone the compulsory medical examination. Temporary asylum, described in Article 12 in the law on Refugees as a status that may be given to a person on the basis of humanitarian considerations even if s/he does not fulfil the asylum criteria (Federal Law No. 4528-1) was thereby "activated" and made available to the Ukrainians. As Viacheslav Bitiutskii of the human rights organization Memorial commented, "There was no need to change the legislation, one only had to implement Article 12 correctly" (01.03.16).

A law amendment dated May 5, 2014 exempted foreign citizens with asylum or TA from the bureaucratic burden of having to obtain formal work permits or patents in order to work in Russia (Federal Law No. 115-FZ from July 25, 2002, version 127-FZ of May 5, 2014, Article 13, Section 4 (11,12): “Access to the labor market.[...].gives foreign citizens the possibility to secure their stay in the Russian Federation and will ease their social adaptation, as the legislation of the Russian Federation does not provide them with any allowances from the federal budget" (Explanatory note to the law project). ${ }^{9}$ In addition to the right to work in Russia without further documents and on equal terms with Russian citizens with regard to taxes, TA holders also have

\footnotetext{
${ }^{9}$ The law "On refugees" promises employment assistance; this amendment to the law on the legal status of foreign citizens was therefore said to make the legislation more coherent.
} 
access to medical assistance. Given for one year at a time, this status is prolonged if the need for protection persists. TA also allowed many Ukrainians to stay for up to six months (in some cases longer) in a state-financed place of temporary accommodation (Punkty vremennogo razmeshcheniia, $P V R$ ). Primary education is compulsory in Russia, so children with TA are to be admitted without further ado into educational institutions. FMS statistics on applications for TA, as well as the number of people granted TA, rocketed from 2,733 applications and 1648 permits issued in 2013, to 245,402 applications and 225,170 permits issued in 2014, of which only 1763 were granted to citizens from other countries than Ukraine. ${ }^{10}$ At the same time, the number of Ukrainian citizens granted asylum proper was less than 300 (Gannushkina 2016). This was probably due to both Russian authorities' general reluctance to grant this status, and the fact that it would prevent travel back to Ukrainian territory, where many had relatives and friends.

Whether the Ukrainian forced migrants were actually entitled to asylum according to the refugee convention was also questionable because of their presumed possibility to flee to peaceful areas within Ukraine. As will be elaborated on below, in October 2014 a "short-cut" was made for people holding TA to simplified citizenship acquisition through the pre-existing State program for voluntary resettlement to the Russian Federation of compatriots abroad.

\section{Citizenship Acquisition in Russia for "Public Relatives"}

While in the early post-Soviet period the citizenship policy of the Russian Federation was inclusive towards former Soviet citizens returning to Russia from other former Soviet republics,

\footnotetext{
${ }^{10}$ In both 2011 and 2012 only around 650 TA permits were issued, an approval rate of approximately $60 \%$.
} 
revisions in 2002 made it less so (Salenko 2012; Shevel 2013a; Abashin 2017). The new restrictions were, according to Eric Lohr, quite openly directed towards reducing the number of non-Russians who could acquire Russian citizenship $(2013,186)$, thus avoiding naturalization of the Central Asian labor migrants who had become numerous due to economic hardship in their newly independent home countries. Difficulties in differentiating between economic and forced migrants, as all these migrants came from CIS countries, may also have prompted this policy change (Vykhovanets and Zhuravskii 2013, 575). Obtaining citizenship was made more difficult for former Soviet citizens unless the state where they were residing had signed a bilateral agreement with Russia that granted simplified access to Russian citizenship for its citizens. ${ }^{11}$

The current law on citizenship in Russia (No. 62-FZ of May 31, 2002) differentiates between access through standard and simplified procedures. ${ }^{12}$ Importantly, those eligible for the simplified procedures may acquire citizenship without the requirement of long-term permanent residency (Chudinovskih 2014). Like many other countries, Russia grants simplified naturalization to close family members; and, since May 2016, also to persons completing a professional education in Russia, individual businessmen and investors who have contributed a certain sum in taxes, as well as highly qualified specialists who have worked at least three years in the country (Federal Law No. 62-FZ, Article 14, Sections 2e,zh, z and i, in red. No. 124-FZ of May 1, 2016). There are also regulations that give simplified access to people who fall under Dumbrava's (2014) definition of "public relatives" (see above). Former Soviet citizens still enjoy

\footnotetext{
${ }^{11}$ Such an agreement existed between Russia and Kyrgyzstan between1996 and 2012, and since 1999 between Russia, Belarus, Kazakhstan and Kyrgyzstan (See Chudinovskikh 2014, 33-37).

${ }^{12}$ According to Olga Chudinovskikh, although there are complaints that it is difficult and time consuming to get Russian citizenship, $99.9 \%$ of those acquiring it get it through simplified (faster) procedures.
} 
simplified access to Russian citizenship if they have not acquired citizenship in their country of residency and are therefore considered stateless (Federal Law No. 62-FZ, Article 14. Section 1b, in red. No. 151-FZ of November 11, 2003). Moreover, as specified in the above-mentioned leaflet, being recognized as a "Russian speaker" can give simplified access to citizenship. When the implementation of this category coincided in time with the escalation of Ukrainian arrivals in Russia, commentators believed that it was tailored to the Ukrainian forced migrants (Rodin 2014). The definition of a "Russian speaker" is as follows:

people (litsa) who know the Russian language and use it on a daily basis at home and in other cultural spheres, when these people or their relatives (in direct line) live or used to live in the Russian Federation or on the territory of the Russian Empire or the USSR within the borders of the Russian Federation (Federal Law 62-FZ from May 31, 2002, Article 14, section 2.1, version No. 157-FZ of June 23, 2014 and No. 307 FZ of October 14, 2014).

An approved "Russian speaker" may apply for citizenship on condition that s/he undertakes to respect the constitution of the RF, has a legal source of income and if possible has renounced his/her former citizenship. Although many Ukrainian forced migrants were likely to meet both the linguistic and the territorial requirement inherent in the definition, they had difficulties obtaining a document from Ukrainian authorities confirming the renouncement of the Ukrainian citizenship. ${ }^{13}$ Russian authorities demanded such proof, although, according to the Russian law on citizenship, lack of official renouncement may be accepted in cases where this is impossible to obtain (Dokuchaeva 03.06.16). The requirement for a legal source of income could also effectively exclude retired persons and the unemployed. One respondent was familiar with the

\footnotetext{
${ }^{13}$ For details on the cumbersome procedures to renounce Ukrainian citizenship see Shevel 2013.
} 
"Russian speaker" category as his mother had been recognized as such. At the time of our interview, however, they were looking for another route to citizenship acquisition for her, as at the age of 58 she had difficulty finding work and was not able to meet the income requirement: "after one year of residency on Russian territory they demand a certificate (spravka) confirming what she is living from. That is either [proof of] official employment (oftsial'noe oformlenie) or she needs to have more than 170,000 on her bank card" $(310,05.03 .16)$. She simply did not have that much money.

\section{Selectivity based on Employability - Fast Track to Russian Citizenship for Working Compatriot Refugees}

What did become the fast track to citizenship for some Ukrainian forced migrants was the preexisting State program for voluntary resettlement to the Russian Federation of compatriots abroad (State program). Respondents in my study were all familiar with this program, referring to it simply as "compatriots," "the program" or "the green booklet" (zelenaia knizhechka), the latter confirming program participant status. This program was launched in 2006/2007 as a mechanism to attract readily integrated labor suited to the needs of Russia's regions. As stated in the program document: "Compatriots, raised in Russian cultural traditions, who speak Russian and who do not want to lose their ties to Russia, are more capable of adapting to the host society and taking part in its system of positive social networks" (Gosudarstvennaia programma 2006 and 2012). Thus, despite the clearly stated preference for "public relatives", the criteria of acceptance are quite pragmatic and potentially selective, stressing the ability to work and the possession of skills (Myhre 2017). After being admitted to this program, participants and their 
family members may apply for a temporary residence permit (TRP) outside the otherwise limited quotas. Once a TRP is obtained, they may immediately and within three years apply for citizenship. ${ }^{14}$ The program also gives some financial support to participants by reimbursing some of the expenses related to relocation to Russia. For their part, participants commit themselves to reside and work in the chosen region for a certain period, often two years. The participating regions (61 as of 2016) develop their own programs based on their needs for labor and are free to set their own criteria for inclusion. ${ }^{15}$ Also program participants have to renounce their former citizenship when applying for Russian citizenship. However, in contrast to the "Russian speakers", for this category a verified copy of their letter of renunciation is sufficient.

In the period 2014-2016 the numbers of "compatriots" resettling in Russia through this State program increased significantly because of the many Ukrainian citizens who applied for participation after arriving in Russia. The total number of "compatriots" arriving in Russia in 2015 was 183,146 - an increase of nearly 80,000 over the year before. Most of them $(110,200)$ were Ukrainian citizens (MVD statistics).

\footnotetext{
${ }^{14}$ Program participants previously got temporary residence permits (TRP) outside the quotas and could apply for citizenship when the TRP was granted. In 2016 the TRP step was replaced by permanent residence permits (PRP) on the route to citizenship. A stated reason was to "optimise the expenses from the Federal budget on the social and housing situation (sotsial'no-bytovoe obustroistvo) of people residing in temporary places of accommodation." It is unclear exactly how, but the PRP allows people to rent housing, register at the place of residency and to take up loans to buy housing. In general, PRP is a more generous status when it comes to rights, allowing one to accumulate pension rights. Perhaps most importantly, while with a TRP one is tied to a particular region for work, a PRP allows free movement around the country.

${ }^{15}$ While not very popular in its first years of existence, changes introduced in 2012/ 2013 made the State program more attractive. See Myhre 2017.
} 
On 8 October 2014 Government Regulation No. 1032 (2014) "On the organization of the work with compatriots from Ukraine who have acquired temporary asylum and wish to take part in the State program" was issued, in reality making Ukrainian forced migrants applicants of priority. Thus, from this point Temporary Asylum was not only "activated", but made into a springboard for speedy citizenship acquisition. The regulation shortened the processing time of their application for participant status to 15 days after submission. If documents that confirmed the Ukrainian forced migrants' education and work experience were lacking, the regions were recommended to conduct interviews to determine the skills and qualifications of the applicants (Government Regulations 1032). In 2016 the legal path from TA to the State program was made permanent, as it was added to the law "On the legal status of foreign citizens" under Article 8 "Permanent residency of foreign citizens in the RF" (Federal Law No. 115-FZ of July 25, 2002, version No 123-FZ, entry into force May 1, 2016, Article 8, Section 3.1, point 3). Access to the program was simplified for Ukrainian citizens with TA in Russia, but the initial focus on skills and employment remained.

The program document from Novosibirsk Region, for instance, listed legal and documented employment in Russia as among the prerequisites for gaining participant status. Volunteer Galina Pyrkh recalled how they had fought with the local authorities to allow single mothers from Ukraine into the program. Often unable to work, they did not fulfil the acceptance criteria, and became underprivileged compared to those who could access temporary residence permits and citizenship through the program. Pyrkh also explained how the program in Novosibirsk had changed because of the forced migrants. Initially, it was intended to attract specialists needed in the region - but now "there is no longer any talk about [special] qualifications. They [the Ukrainian citizens] become participants to get the documents that is how it is [...] qualified, not 
qualified, most importantly you find official work and become a participant". Thus, according to her, the local authorities had made the program more accessible for the Ukrainian refugees by ignoring the initial requirement for special qualifications (06.06.16).

Respondents in Novosibirsk as well as in regions in the Central Federal District confirmed that official employment was a prerequisite for getting participant status in the program, and thus for full integration into the community of value: "Official employment was necessary. Unemployed and people not able to work were not given [access to] the program.” This respondent added that persons with criminal records were not accepted: "Because they have more than enough of their own criminality here, why should they accept any from the outside?" $(505,09.06 .16)$. Another had been worried that her husband would not be accepted in the program because he could not document his education, but they were told "We don't care what profession he had there - where he gets settled, there he will work" $(503,05.06 .16)$.

The employment requirement for entering the State program seemed to vary slightly across regions, being compulsory in some, preferable in others. Respondents also noted how local authorities had gradually become stricter, and some even said that they could understand this.

Author: “...To participate in the program, were there any special requirements?”

Respondent: "Of course. There is a special bundle of documents dictated by the program. Until New Year (2016) there were concessions (l'goty), UFMS [the local FMS departments] closed their eyes, if you are not working officially. Now they've toughened it. I understand that: when you work officially there are transfers to the [state ] budget that cover the gaps [deficits] that have been formed due to the temporary residence centers (PVRs), humanitarian aid. I think it is quite normal, you have to contribute to the treasury" $(106,19.03 .16)$. 
This was confirmed by respondents in Voronezh, where a woman who had arrived in February 2015 stated that work on the territory of Voronezh Region was a requirement for entering the program (307, 03.03.16). However, a man who had arrived in the city already in August 2014 found no special requirements:

I wrote everywhere that I was temporarily unemployed. Since it is impossible to find official work without documents, all jobs are illegal...They say, [when] you get a TA, then you can work legally (ofitsial'no oformit'sa). But even with a TRP I couldn't be hired officially (normal'no oformit'sa). They hired me unofficially and temporarily...

None of the respondents who joined the program mentioned being a descendant of someone living on the territory of the Russian Federation as a prerequisite for gaining participant status, nor had they been questioned about their national self-identification. Work, proof of good health and a clean record were emphasized at admission, suggesting that in its integration policies Russia puts economic before other interests. However, some of the respondents were of the impression that they - people from Lugansk and Donetsk - had easier access to the program than other migrants in Russia. In an interview with the online newspaper Zhurnalistskaya Pravda, the head of the Ukrainian political emigrants' union, Larisa Shesler, praised the State program as "one of the few programs for the emigrants that really work. It is not a coincidence that 200,000 former Ukrainian citizens found work and a place to live and work (mesto dlya ustroistva) via this program." Shesler was quick to add, however, that the problem with the program was that "it was created to attract labor and not for real resettlement of compatriots." Because of age limits, people close to or past retirement age could not take part in the program, and getting into the program had gradually become more difficult, as many regions were implementing additional 
criteria like length of residence in the region (Urzhumov 2016). That evaluation coincides with the findings of this study.

\section{Selectivity based on Mobility - "They help us if we go where they order us"}

As Ukrainian citizens started to flee to Russia, numerous places of temporary accommodation (PVR) were set up in hotels, summer camps for children, rehabilitation centers and other available facilities. To ease the pressure on the regions bordering on Ukraine, redistribution of people throughout the country was organized and a one-way ticket to a destination in one of Russia's regions, partly chosen by the Ukrainians themselves, was paid for by the Russian authorities. Respondents reported that access to any legal status, also TA, was very difficult in the border regions. One described the situation in Belgorod Region as follows: "It was impossible to get into the migration services, there was such a crowd. The only thing the FMS could do was to send people on to one of the [other] regions" $(403,20.03 .16)$.

Several respondents had found it necessary to leave regions where access to temporary asylum and/or other documents was difficult: "To begin with we went to relatives in the Rostov Region, but there they did not process the documents and we were directed by the migration services to Lipetsk Region...” (201, 02.03.16). A man who had first gone to relatives in St Petersburg soon understood that "doing the documents" there "will take very long, it is hopeless, and you need a lot of money. I stayed there only as a guest. Then I went to Tula, and got TA immediately. Now, further down the path [to citizenship]" $(106,19.03 .16)$. Thus people were either directed by the FMS to regions where documents could be obtained, that is, regions where population increase was deemed desirable by Russian authorities, or they went on to such regions on their own initiative after encountering difficulties with the migration regime elsewhere. 
The Civic Assistance Committee (CAC) report (2015) explains how some federal subjects made access to TA virtually impossible. Migration hubs like Moscow, Moscow Region and St Petersburg stopped issuing TA to people unless they had close relatives with accommodation. The same was true of other places where the authorities wanted to reduce rather than encourage the migrant inflow, like Stavropol Region, Chechnya, and the annexed Crimea (CAC report 2015). ${ }^{16}$ There seemed to be a clear intention to direct forced migrants to regions according to the interests of the state, sometimes against the interests of the forced migrants themselves. Jobs, for instance, are more readily available in Moscow and Moscow Region, and wages considerably higher there than in most other regions. This was confirmed by respondents who were staying in these regions with labor migrant status although they had fled from war. Thus, the choice of region affected the legal status of the forced migrants. As a middle-aged woman from Donetsk, now living in the Moscow region, confirmed when I asked about her migration status:

\footnotetext{
None. You see, Russia’s policies look like this: they help us if we go where they order us to go... There are no quotas in Moscow Region (MR). The government is distributing quotas. If there are quotas, you can go here and there... Of course they suggest the Urals, Siberia, such places. Where there is no infrastructure, nothing. Some villages where Russians do not go. But here there are no quotas. We are not allowed to stay here $(401,14.02 .16)$.
}

Although she mentioned poorly developed infrastructure elsewhere in Russia, her main reason for remaining in MR was the gap in salaries. Previously, she had stayed with relatives

\footnotetext{
${ }^{16}$ The CAC is a Human Rights Organization working extensively on issues related to migrants and refugees in Russia; it is headed by Svetlana Gannuskhina.
} 
in Smolensk, where living conditions, she explained, were much worse. Now she was earning RUR 30,000 as a kindergarten teacher, whereas in Smolensk she would get only 8000 (401, 14.02.16). In Moscow Region, she had registered as a labor migrant and was working officially by paying for the patent. Her husband, however, had problems finding a permanent position, and obtaining a patent was too expensive when his income was unstable, so he took on illicit temporary work. As the local authorities in Moscow and Moscow Region agreed to extend the validity of migration cards of Ukrainian citizens from Lugansk and Donetsk, this gave people the opportunity to stay legally on Russian soil while providing for themselves by working in the shadow sector. In September 2016 this was still common practice among people from Lugansk and Donetsk in Moscow (407, 20.09.16).

Although TA entitled people to work on equal terms with Russian citizens, several respondents complained that many employers were hesitant to hire people with this status:

When we arrived in Novosibirsk we immediately got (oformili) TA. The certificate we got within a week. But that was just the beginning. Then we had to find official employment, with a work contract. That was very difficult because almost no employers would [officially] hire a foreigner with our TA document. And a (work) contract was needed to enter the [State program] $(501,31.05 .16)$.

While work was needed in order to get citizenship, some also saw citizenship as a prerequisite for getting a proper job. Many jobs "where the salary is more or less ok...require Russian citizenship.” This respondent added that whereas earlier the employment office had been helpful in directing the forced migrants to vacant positions, "now they say that it is a priority for Russian citizens to get work $(104,25.02 .16)$. For respondents who already had returned to Donbas or were determined to return, the problems in getting official employment and the low wage levels in many regions were decisive: 
Those able to stay here are the ones who have relatives here, money to buy a flat or who have nothing to lose [back home] because their own home was destroyed ..., we lived in Lipetsk for almost two years, we got no help from the state. The only thing we got was TA status that allows employers to hire you officially, but that seldom happens. On an average Lipetsk wage of 20,000 RUR, when the rent for a flat is 10,000 a family of three cannot live there, let alone save money to buy a place of their own. So we are going home...(200, 27.02.16).

However, people's experiences and the picture they present of the Russian migration and citizenship regime were not unambiguous. Several of those who followed the advice of the FMS and let themselves be directed to another region were satisfied with how they had been "resettled" to places of temporary accommodation. They confirmed that in the beginning they were helped with documents and provided with food, and that during their stay there they were able to "settle in (osvoit'sa), and find work" (501, 30.05.16).

\begin{abstract}
We were told by the FMS that we could make a request in Moscow and they will send us to Tula. That is what we did. It was a room in a hotel, we got food three times a day and they registered us... We lived there one year. Exactly long enough to get the documents, to find work and a place in the kindergarten for our children $(404,23.02 .16)$.
\end{abstract}

Some respondents reported that they got information from the FMS about the State program while in a temporary place of accommodation, and described the FMS staff as helpful and efficient (201, 02.03.16). However, how people had experienced the FMS offices varied greatly: some described them as "not particularly helpful" or "awful," others as "great."

The FMS in X region I evaluate as great. They worked well, I have no complaints. It was well organized, everything was done in due time...I cannot compare it with Belgorod, because there I couldn't even get in... the queues lasted for weeks....Some entered (prolazili) illicitly (po blatu) (403, 20.03.16). 
According to Vladimir Malakhov $(2014,1075)$, corruption is "the main factor determining current immigration politics in Russia," and he notes how "Russian officials at the local level are subjected not to legal-rational logic but to the logic of material interests". As further explained below, the Ukrainian forced migrants witnessed and experienced various kinds of corrupt practices.

\section{Circumventing Regulations}

Just as TA was hard to get in the large migration hubs, acquiring temporary residency and citizenship was also more difficult and time-consuming there, as the State program was not available. A woman who was staying in Moscow mainly because her cousin was living there complained about difficult access to residence permits due to the restrictive regional quotas:

I applied to get the quota [for TRP) several times - temporary residence on Russian territory. The first time they refused us, the second time, and the third time I came there, there is a queue you have to sign up three days in advance - horrible. The third time I came and I had to copy some documents, I brought the receipt to a different office and the girl told me "Don't waste your time, it is all rubbish (fignia). The quotas here were all sold out a long time ago (vse kvoty davno vykuplennie) (405, 28.03.16).

When the respondent asked where she could buy the TRP, at what firm or company, no one would give her the address.

Some respondents circumvented these limitations by signing up for the State program in one region while commuting to Moscow for work. A young father who had fled from Lugansk with his wife, mother and two children, explained how he had actually been advised by staff 
at the migration services to take up illegal work elsewhere, while proceeding with the citizenship procedures in their region. He explained that he could simply not provide for his family on the local salary in his region of residency. "The family is big, someone had to feed them. I started to search for work, anywhere. Looked at Moscow as an alternative because there they pay the most" $(403,20.03 .16)$. As the State program ties one to a region for a certain amount of time, once Russian citizenship is achieved that makes working elsewhere illegal. The respondent said that several of his friends did the same - acquired citizenship through the program in one of the other Central Russian regions, while commuting to Moscow for unofficial work.

\footnotetext{
My other friends live in Moscow. Doing the program, only in Orel [region]....His wife and child are doing it there. Another one is living in the Moscow Region.[...] and doing the program in Lipetsk $(403,20.03 .16)$.
}

That the State program tied people to a specific region was mentioned by several as a drawback whereas others did not really see it as an obstacle. A respondent who gained participant status in Lipetsk but was now working in a region closer to his home in Ukraine explained:

It's like this - if I go to Lipetsk, get registered....I can live freely on equal terms with Russian citizens, I will have medical insurance...I can work. [...] As soon as I go to another region, officially I cannot work in a different region, as far as I have understood that document [...]There are lots of problems with this" (208, 18.03.16).

Access to the program thus depended on the forced migrants' willingness to settle in "less attractive" regions - if not necessarily rural backwaters. For Ukrainian forced migrants staying in a region where the program was available, the processing of their application for participant 
status was speeded up significantly. Thus, their choice of region and their ability to work partially determined their possibilities for fast-track citizenship.

\section{Finding and Paying the Way to Legality - Registration and Citizenship}

Although access to documents proved much easier in some regions than in others, respondents in all regions included in this study reported similar bureaucratic problems. A main issue was the compulsory registration at the place of residence. The legal framework and procedures concerning registration of foreign citizens in Russia will not be elaborated on here, but registration is compulsory and required in order to legalize one's stay. Documentation of registration must be produced, for instance, when applying for residence permits and citizenship, and also when formalizing employment. Migrants repeatedly reported difficulties in obtaining official registration in Russia (see also Light 2016; Heusal and Aitamurtu 2017).

In Ukraine we were not used to that, to be honest. We don't have it. You are registered in one place and can live and work in a different place. In Ukraine that is not important. Here registration is everything. Without registration you are nobody. And people do not agree to do it [for you] just like that. Everybody wants money $(503,05.06 .16)$.

The problem of registration arises when the applicant does not own the place where $\mathrm{s} /$ he is living, and that means the vast majority of forced migrants from Ukraine. Although tenants of an apartment are required to register there, there is nothing that compels the owner of the building to register them, and if he is willing to do so, that will probably incur an extra charge. Several respondents reported that they had made an agreement with someone and registered at a different address than where they were actually staying, although since 2013 such practice is considered a 
criminal offence by law ${ }^{17}$. Whereas some had been able to find people willing to register them for free, as a favor, others reported paying a fixed sum for a temporary registration. "No one wants to register you. Everywhere you have to pay for it...Registration is one of those weak points (slabye zven'ia) [of the regulations/ policy]" (403, 20.03.16).

One respondent described a situation where dishonest people make money from the migrants' need for registration:

Yes, there are big problems with registration here. There are very few people who are ready to register refugees at their place. And if you find them, then they ask for such big sums of money that we can't afford it (nam ne potianut'). Many con-men take advantage of this; once we ran into some who made a fake registration for us...Afterwards when we came to submit the documents for citizenship, we nearly got arrested for forgery $(501,31.05 .16)$.

Thus, Ukrainian citizens, despite their ethno-cultural similarity with Russians, encountered problems similar to those of other migrant groups in Russia. (See Reeves 2013 and 2015)

A woman residing in Lipetsk had heard that there was a possibility to get registered with help from the authorities:

A girl told me that 'if you have nowhere to register' - she gave some information -'then you have to go somewhere and say that you don't have anywhere to register. And they are obliged to register you somewhere. But where this is, where to go I do not know "(207, 16.03.16).

Finally she found a girl who agreed to register her "based on friendly relations," but would otherwise, as she said, have had to inquire further about this other possibility: "There is supposed

17 For details on the legislation in Russian see: http://www.consultant.ru/law/hotdocs/30316.html 
to exist such a possibility somewhere, but it is not advertised and nobody knows about it...Everybody searches, buys and so on" $(207,16.03 .16)$. A woman from Donetsk, working in Moscow, had registered at her workplace. If the employer agrees to it, she said, that is a legal option. However, no other respondents mentioned that possibility, which suggests a certain lack of information as to what is possible and legal.

As a new registration is needed for each step on the way to citizenship, this was a recurrent problem for some. Two respondents reported that the authorities in their regions had started to punish landlords who registered migrants at their address when this was not the actual place of residence, thus enforcing the law and at the same time contributing to the "administrative production of migrant 'illegality"' by making the compulsory registration unavailable (Reeves: 2015, 120):

And the lady who registered me already said she would not do it again, because they've started fining people, and she got afraid. They've started fining those who register and those that they register who do not live at the place of residence $(207,16.03 .16)$.

Nearly all respondents told of long queues at the migration services. In one region in Central Russia several respondents said it was possible to pay the local migration authorities to get quicker access to documents: "the situation is like this: if you want to do everything faster, then you have to pay..." $(306,03.03 .16)$.

Everything can be bought, if you want to submit the documents for TRP - there is a window for paid services (platnoe okoshko). The administrator tells you the prices, all that is needed, if you pay 5000, they have this service, they prepare the documents for you, make copies of the documents and set up a meeting $(310,05.03 .16)$. 
According to the respondent, this was not a corrupt practice, but an officially established possibility to pay for fast service at the FMS office. Much in the same way as a visa to Russia is more expensive if issued by the consular section on the same day as requested, a residence permit could be obtained faster if the applicant is willing to pay more.

A respondent in Moscow explained how she had been offered the possibility of paying for a fasttrack residence permit and citizenship at a law firm:

You need either contacts, or a lot of money, which I don't have. I also went to a lawyer for consultation. They offered to send our documents somewhere, to Ekaterinburg, to obtain refugee status there, and then apply for the resettlement program. In half a year we would get the status [residence permit or citizenship], but it would cost around 150,000. I said: 'Excuse me, but I don't even have 10,000 in my pocket. And I still have to find work. [...] We continue to live on the territory of Russia as Ukrainian citizens only without any documents. We have temporary registration that they prolong if needed. Neither the quota [for TRP], nor citizenship [is possible to obtain], although it is very much needed, because our child is at school it is needed. She has no insurance, I have no insurance. If something happens I can't even go to the hospital $(405,28.03 .16)$.

Here, Ukrainian forced migrants felt vulnerable much in the same way as other migrants in Russia. Being able to handle the registration requirement and other financial burdens related to their formal stay in Russia hinged on their general financial situation. Whereas some did not mind "adding to the pension" of some elderly Russians by paying them to arrange registration $(504,09.06 .16)$, for others these bureaucratic hurdles and expenses delayed the process of being accepted into the State program and eventually acquiring temporary residency and citizenship. 


\section{Conclusions}

Due to conflict and war in Ukraine in 2014-2016, many Ukrainian citizens fled to neighboring Russia. Russia made significant efforts to provide shelter, and "activated" and made amendments to existing legal mechanisms in order to integrate them. Expected to fit nicely into the Russian community of value due to their ethno-cultural similarity, the Ukrainian forced migrants were welcomed as potential Russian citizens and as a much-needed labor reserve. However, as this study has shown, while ethno-cultural considerations may privilege Ukrainian forced migrants in Russia, residence permits and citizenship are not unconditionally granted on the basis of ethnocultural links. Instead, the Russian authorities have tried to control and distribute these refugees and migrants for the benefit of the state, according to principles of selectivity and economic interests - giving privileged access to permanent residency and citizenship to working-age people willing to settle in regions where population growth and more workers are deemed necessary.

The study thus describes a migration and citizenship regime with considerable regional differences regarding migrants' access to various legal statuses, and where Ukrainian "compatriot-refugees" encounter many of the same corrupt practices and inconsistencies as do other migrants. The study also shows how the Russian authorities have gradually become more restrictive and selective, differentiating between Ukrainian citizens from Lugansk/ Donetsk and those from other Ukrainian regions, privileging the former only; and enforcing the employment requirement for admission to the State program. The ability to work and willingness to reside where the authorities want is an entry card to the community of value. However, permanent residency and citizenship are also available to those able to circumvent or pay their way through 
the obstacles encountered - taking advantage of the flexibility inherent in a slightly inconsistent system. 


\section{References}

Abashin, Sergey. 2017. "Migration policies in Russia. Laws and Debates" in Migrant Workers in Russia. Global Challenges of the Shadow Economy in Societal Transformation, edited by AnnaLiisa Heusala and Kaarina Aitamurto. London: Routledge

Anderson, Bridget. 2012. "What does 'The Migrant' tell us about the (Good) Citizen?” Working Paper No. 94, Center on Migration, Policy and Society, University of Oxford.

Anderson, Bridget. 2013. Us and Them? The Dangerous Politics of Immigration Control. Oxford: Oxford University Press

CAC. 2015. “Kommitet 'Grazhdanskoe sodeistvie' 2015: Rossiya kak strana ubezhishcha Doklad ob ispolnenii RF Konventsii o statuse bezhentsev 1951 goda” (Civic Assistance Committee 2015, Russia as a country of asylum. Report on the RF's implementation of the 1951 Refugee Convention)

Chudinovskikh, O. S. 2014. Gosudarstvennoe regulirovanie priobreteniya grazhdanstva Rossiiskoi Federatsii: Politika i Tendentsii, Izdatel'skii dom Vysshei sholy ekonomiki, Moskva

De Haas, Hein, Katharina Natter and Simona Vezzoli. 2016. “Growing Restrictiveness or Changing Selection? The Nature and Evolution of Migration Policies." International Migration Review, 1-44. doi:10.1111/imre.12288.

Domcheva, Elena and Tat'iana Panina. 2014. "Dom i khata”. Rossiîskaia gazeta, September 23. http://www.rg.ru/2014/09/22/migranty-site.html

Dumbrava, Costica. 2014. Nationality, Citizenship and Ethno-cultural Belonging. Basingstoke: Palgrave Macmillan 
Explanatory note to the law project, "Poiasnitel'naia zapiska k proektu Federal'nogo zakona "O vnesenii izmeneniia v stat'iu 13 Federal'nogo zakona “'O pravovom polozhenii inostrannykh grazhdan v Rossiiskoi Federatsii" (On an amendment to Article 13 of the Federal Law "On the legal status of foreign citizens in the Russian Federation"). 2014. http://allmigration.ru/upload/445048-6.pdf

Federal Law No. 4528-1 of February 19, 1993, version of December 22, 2014, "O bezhentsakh" (On refugees)

Federal Law No. 62-FZ of May 31, 2002, "O grazhdanstve Rossiiskoi Federatsii (On citizenship of the Russian Federation)," version of May 1, 2016.

http://www.consultant.ru/document/cons_doc_LAW_36927/255a00ae21c0db18ec7a435d44c9ec 751582ea99/

Federal Law No. 115-FZ of July 25, 2002, “O pravovom polozhenii inostrannykh grazhdan v Rossiiskoi Federatsii (On the legal status of foreign citizens in the Russian Federation). http://www.consultant.ru/document/cons_doc_LAW_37868/

Gannushkina, Svetlana. 2016."Polozhenie migrantov". Prava Cheloveka v Rossiiskoi Federatsii, sbornik dokladov o sobytiakh 2015 goda. Moskovskaya Khel'sinkskaya gruppa 2016, pp. 164 165

Gosudarstvennaia programma. 2006. “Gosudarstvennaia programma po okazaniiu sodeřstviia dobrovol'nomu pereseleniiu v Rossiřskuiu Federatsiiu sootechestvennikov, prozhivaiushikh za rubezhom". http://www.rg.ru/2006/06/28/ukaz-pereselenie.html 
Gosudarstvennaia programma. 2012. "Gosudarstvennaia programma po okazaniiu sodeřstviia dobrovol'nomu pereseleniiu v Rossiǐskuiu Federatsiiu sootechestvennikov, prozhivaiushikh za rubezhom". http://www.rg.ru/2012/09/17/programma-dok.html

Government Regulation 690 (postanovlenie) of June 22, 2014, “O predostavlenii vremennogo ubezhishcha grazhdanam Ukrainy na territorii Rossiskoi Federatsii v uproshchennom poriadke" (on the Granting of TA for Citizens of Ukraine on the Territory of the Russian Federation through simplified procedure). http://government.ru/media/files/41d4f3a5c06af7f5f50e.pdf

Government Regulation No. 1032 of October 8, 2014. “Ob organizatsii raboty s sootechestvennikami, postoianno prozhivaiushchimi na territorii Ukrainy, pribyvshimi na territoriiu Rossiiskoi Federatsii, poluchivshimi vremennoe ubezhishche v Rossiiskoi Federatsii i zhelaiushchimi priniat' uchastie v Gosudarstvennoi programme po okazaniiu sodeistviia dobrovol'nomu pereseleniiu v Rossiiskoi Federatsiiu sootechestvennikov, prozhivaiushchikh za rubezhom" (On work with compatriots, permanently living on Ukrainian territory who have come to the Russian Federation, gained temporary asylum and want to participate in the State program for voluntary resettlement to the Russian Federation of compatriots abroad). https://rg.ru/2014/10/13/pereselency-site-dok.html

Heusala, Anna-Liisa and Kaarina Aitamurto (eds). 2017. Migrant Workers in Russia: Global Challenges of the Shadow Economy in Societal Transformation. London: Routledge

Light, Matthew. 2017. Fragile Migration Rights. Freedom of Movement in Post-Soviet Russia. London: Routledge 
Kontseptsiia 2007. “Kontseptsiia demograficheskoi politiki Rossiiskoi Federatsii na period do 2025 goda”. Ukaz Prezidenta RF No. 1351, October 9, 2007.

www.demoscope.ru/weekly/knigi/koncepciya/koncepciya25.html.

Lohr, Eric. 2012. Russian Citizenship. From Empire to Soviet Union. Cambridge, MA: Harvard University Press

Malakhov, Vladimir S. 2014. "Russia as a New Immigration Country: Policy Response and Public Debate”. Europe-Asia Studies 66 (7): 1062-1079

Myhre, Marthe Handå. 2017. “The State program for Voluntary Resettlement of Compatriots. Ideals of Citizenship, Membership and Statehood in the Russian Federation". Russian Review, Oct. 2017

MVD statistics on the program, "Monitoring gosudarstvennoi programmy". https://xn-b1aew.xn--p1ai/mvd/structure1/Glavnie_upravlenija/guvm/compatriots/monitoring

Pamiatka dlia grazhdan Ukrainy vynuzhdenno pokinuvshikh territoriiu Ukrainy (Leaflet for citizens from Ukraine who were forced to leave Ukrainian territory).

http://trubnikovboradm.ru/tinybrowser/files/ukraina/pamyatka.pdf

Petrov, Ivan. "V MVD rasskazali skol'ko Ukraintsev stali rossiianami." Rossiiskaia gazeta, October 26, 2016. https://rg.ru/2016/10/27/v-mvd-rasskazali-skolko-ukraincev-stalirossiianami.html

Pilkington, Hilary. 1998. Migration, Displacement and Identity in Post-Soviet Russia. London: Routledge 
Reeves, Madeleine. 2013. “Clean Fake: Authenticating Documents and Persons in Migrant Moscow". American Ethnologist 40(3): 508-524

Reeves, Madeleine. 2015. "Living from the Nerves: Deportability, Indeterminacy, and the 'Feel of Law' in Migrant Moscow”. Social Analysis 59 (4): 119-136

Rodin, Ivan. 2014. "Vse Ukraintsy mogut stat' 'nosiletiami russkogo iazyka.” Nezavisimaiia gazeta, April 4. http://www.ng.ru/politics/2014-04-04/3_russian.html

Salenko, Alexander. 2012. Country Report: Russia. EUDO Citizenship Observatory. Florence: European University Institute

Shevel, Oxana 2013a. "The Politics of Citizenship Policy in Russia.” Post-Soviet Affairs 28 (1):, $111-147$

Shevel, Oxana. 2013b. Country Report: Ukraine. EUDO Citizenship Observatory, revised and updated. Florence: European University Institute

Schenk, Caress. 2016. “Assessing Foreign Policy Commitment through Migration Policy in Russia.” Demokratizatsiya: The Journal of Post-Soviet Democratization 24 (4): 465-490

“Ukrainskie bezhentsy: vozmozhnosti poluchit' zashchitu v RF segodnia i zavtra.” 2014. RIA Novosti, July 26. http://ria.ru/society/20140721/1016892520.html

“Ukraintsy s 1 avgusta dolzhny oformliat' svoi status v Rossii za 90 dnei." 2015. RIA Novosti, August 1. https://ria.ru/society/20150801/1156569878.html

UNHCR Country Statistics, available at http://www.unhcr.org/56655f4cb.html 
Urzhumov, Il'ia. 2016. “Larisa Shesler: 'V Rossii nyzhna struktura dlya bezhentsev s Ukrainy.'" Zhurnalistskaia Pravda, August 31. https://jpgazeta.ru/larisa-shesler-v-rossii-nuzhna-strukturadlya-bezhentsev-s-ukrainyi/

Vashchenko, Vladimir. 2015. "Ukraintsam pridetsa vyiti iz teni." gazeta.ru, February 22. https://www.gazeta.ru/social/2015/07/22/7652593.shtml

Vykhovanets. O and A. Zhuravskii. 2013. "Vozvrashchenie sootechestvennikov". In Migratsiia v Rossii 2000 - 2012 v trekh tomakh, chast' 1, HP RSMD 2013 


\section{Appendix: Table of respondents}

Coding:

First number-region where the respondent was or had been residing/working in Russia (often also the region where the interview took place).

Second number - code-number of respondent

$1-$ Tula $101-106$

2 - Lipetsk $200-207$

3 - Voronezh $301-310$

4 - Moscow and Moscow region $401-407$

5 - Novosibirsk $501-506$

Bitiutskii, ViachesIav Ilich, representative for the human rights organization Memorial, at the Human Rights House in Voronezh, March 1, 2016

Dokuchaeva, Aleksandra, researcher at the CIS Institute, Department for Diaspora and Integration, at the CIS Anniversary Conference, June 3, 2016

Prykh, Galina, volunteer in Novosibirsk, at a cafe in Novosibirsk, June 6, 2016

\begin{tabular}{|l|l|l|}
\hline Respondent & Date & Medium \\
\hline 104 & February 25, 2016 & Face-to-face (FTF) \\
\hline 106 & March 19, 2016 & Telephone interview (TI) \\
\hline
\end{tabular}




\begin{tabular}{|l|l|l|}
\hline 200 & February 27, 2016 & Vkontakte (VK) \\
\hline 201 & March 2, 2016 & VK \\
\hline 207 & March 16, 2016 & TI \\
\hline 208 & March 18, 2016 & TI \\
\hline 306 & March 3, 2016 & VK \\
\hline 307 & March 3, 2016 & FTF \\
\hline 310 & March 5, 2016 & Skype \\
\hline 401 & February 14, 2016 & FTF \\
\hline 403 & March 20, 2016 & VK \\
\hline 404 & February 23, 2016 & TI \\
\hline 405 & March 28, 2016 & FTF \\
\hline 407 & September, 20, 2016 & VK \\
\hline 501 & May 30, 2016 & FTF \\
\hline 503 & June 5, 2016 & June 9, 2016 \\
\hline 504 & June 9, 2016 & \\
\hline 505 & & \\
\hline
\end{tabular}

